\title{
Evaluasi Surveilans Epidemiologi Demam Berdarah Dengue (DBD) di Puskesmas Pudakpayung Semarang Tahun 2018
}

\section{Evaluation of Epidemiological Surveillance of Dengue Hemorrhagic Fever (DBD) in the Pudakpayung Semarang Health Center in 2018}

\author{
Dewi Puspito Sari ${ }^{1}$ \\ Prodi Kesehatan Masyarakat Universitas Veteran Bangun Nusantara Sukoharjo ${ }^{l}$ \\ Email : sari.puspito.dp@gmail.com
}

\begin{abstract}
Dengue Hemorrhagic Fever is a contagious disease caused by dengue virus that causes death. The high case of Dengue Hemorrhagic Fever in the city of Semarang has a negative impact and social and economic losses including panic in the family, death of family members, and reduced age of the population's expectations. Pudakpayung Health Center is the Semarang City Health Office technical implementation unit that organizes health development and is the spearhead of Government health services through the provision of basic health services to the community where the working area of the Pudakpayung Health Center is endemic for dengue disease. Various efforts have been made by the Pudakpayung Health Center to control Dengue Hemorrhagic Fever, one of the countermeasures is with Epidemiological Surveillance. The purpose of this study was to evaluate the Epidemiological Surveillance of Dengue Hemorrhagic Fever in the Pudakpayung Health Center Semarang in 2018.

This type of research is qualitative with an evaluation study design with 4 informants. Data collection techniques using structured interviews and observation. The conclusions of this research are the lack of management staff of the Epidemiology Surveillance program, the lack of funding allocation for epidemiological surveillance programs for Dengue Hemorrhagic Fever, lack of official vehicles, administrative disorder, updated information on Dengue Hemorrhagic Fever has not been done, data collection, data completeness and accuracy have exceeded $80 \%$ and vertical and horizontal reports have been carried out routinely.
\end{abstract}

Keywords: Dengue Hemorrhagic Fever, Pudakpayung, Puskesmas, Semarang, Surveillance

\begin{abstract}
ABSTRAK
Demam Berdarah Dengue merupakan penyakit yang mudah menular disebabkan oleh virus dengue hingga menyebabkan kematian. Tingginya kasus Demam Berdarah Dengue di Kota Semarang memberikan dampak buruk dan kerugian secara sosial dan ekonomi diantaranya kepanikan dalam keluarga, kematian anggota keluarga, dan berkurangnya usia harapan penduduk. Puskesmas Pudakpayung adalah unit pelaksana teknis Dinas Kesehatan Kota Semarang yang menyelenggarakan pembangunan kesehatan dan merupakan ujung tombak pelayanan kesehatan Pemerintah melalui pemberian pelayanan kesehatan dasar bagi masyarakat dimana wilayah kerja Puskesmas Pudakpayung termasuk daerah endemis penyakit DBD. Berbagai upaya telah dilakukan Puskesmas Pudakpayung untuk mengendalikan penyakit Demam Berdarah Dengue salah satu penanggulangannya dengan Surveilans Epidemiologi. Tujuan penelitian ini adalah untuk
\end{abstract}


mengevaluasi Surveilans Epidemiologi Demam Berdarah Dengue Di Puskesmas Pudakpayung Semarang Tahun 2018.

Jenis penelitian ini adalah kualitatif dengan rancangan studi evaluasi dengan informan berjumlah 4 orang. Teknik pengambilan data menggunakan wawancara terstruktur dan observasi. Simpulan dari penelitian ini adalah masih kurangnya tenaga pengelola program Surveilans Epidemiologi, kurangnya alokasi dana program surveilans epidemiologi Demam Berdarah Dengue, kurangnya kendaraan dinas, ketidakrapian administrasi, pembaharuan informasi Demam Berdarah Dengue belum dilakukan, pengumpulan data, kelengkapan dan ketepatan data sudah melebihi $80 \%$ dan laporan secara vertikal maupun horizontal telah dilaksanakan secara rutin.

Kata kunci: Demam Berdarah Dengue, Pudakpayung, Puskesmas, Semarang, Surveilans

\section{PENDAHULUAN}

Demam Berdarah Dengue (DBD) masih merupakan salah satu masalah kesehatan masyarakat yang utama di Indonesia (Kementerian Kesehatan RI, 2018). Seiring dengan meningkatnya mobilitas dan kepadatan penduduk, jumlah penderita dan luas penyebarannya semakin bertambah. DBD merupakan penyakit menular yang disebabkan oleh virus dari golongan Arbovirus group A dan B yang berasal dari gigitan vector (Suwanmanee et al., 2018). DBD merupakan penyakit infeksi yang disebabkan dan ditularkan melalui nyamuk Aedes aegypti dan Aedes albopictus yang ditemukan didaerah tropis dan subtropis diantaranya di Indonesia hingga bagian utara Australia (Kementerian Kesehatan RI, 2018). Pada banyak daerah tropis dan subtropis, penyakit DBD adalah endemik yang muncul sepanjang tahun, terutama saaat musim hujan ketika kondisi optimal untuk nyamuk berkembang biak. Biasanya sejumlah besar orang akan terinfeksi dalam waktu yang singkat (wabah) (CDC, 2010). Penyakit ini tidak hanya sering menimbulkan Kejadian Luar Biasa (KLB) tetapi juga menimbulkan dampak buruk sosial dan ekonomi. Kerugian sosial yang terjadi antara lain karena menimbulkan kepanikan dalam keluarga, kematian anggota keluarga, dan berkurangnya usia harapan penduduk.(Yuningsih, 2018),(Nurhidayati et al., 2015),(Djawa, Hariyanto and Ardiyani, 2017).

Di Indonesia DBD pertama kali ditemukan di Surabaya dimana sebanyak 58 orang terinfeksi dan 24 orang diantaranya meninggal dunia, dengan Angka Kematian (AK) mencapai 41,3 \%. Sejak saat itu, penyakit ini menyebar luas ke seluruh Indonesia (Kementerian Kesehatan RI, 2018). Jumlah kasus DBD fluktuatif setiap tahunnya. Data dari Direktorat Pencegahan dan Pengendalian Penyakit Tular Vektor dan Zoonotik, Kemenkes RI, pada 2014 jumlah penderita mencapai 100,347, 907 orang diantaranya meninggal. Pada 2015, sebanyak 129,650 penderita dan 1,071 kematian. Sedangkan di 2016 sebanyak 202,314 penderita dan 1,593 kematian. Di 2017, terhitung sejak Januari hingga Mei tercatat sebanyak 17.877 kasus, dengan 115 kematian. angka kesakitan atau IR(IR) di 34 provinsi di 2015 mencapai 50.75 per 100 ribu penduduk, dan Insiden Rate (IR) di 2016 mencapai 78.85 per 100 ribu penduduk. Angka ini masih lebih tinggi dari target IR nasional yaitu 49 per 100 ribu penduduk. Penyakit DBD masih merupakan permasalahan serius di Provinsi Jawa Tengah, terbukti 35 kabupaten/kota sudah pernah terjangkit penyakit DBD. IR DBD Provinsi Jawa Tengah pada tahun 2016 sebesar 43,4 per 100 ribu penduduk, mengalami penurunan bila dibandingkan tahun 2015 yaitu 47,9 per 100 ribu penduduk. Keadaan tersebut menunjukkan bahwa IR DBD Jawa Tengah lebih rendah dari target nasional karena kurang dari 51/100 ribu penduduk namun lebih tinggi dibandingkan dengan target Rencana Pembangunan Jangka Menengah Daerah (RPJMD) (<20/100 ribu penduduk). Tahun 2016 jumlah kasus DBD sebanyak 14.376 kasus dengan IR sebesar 42,26 per 100 ribu penduduk dan AK sebesar 1,48 \%.(Infodatin DBD, 2017) 
Dari data tersebut diatas menunjukkan penurunan kasus namun jumlah kematian kasus DBD justru meningkat (PPJT, 2009).

Penyakit DBD di Kota Semarang masih menjadi salah satu masalah kesehatan dan sering mengakibatkan kepanikan di masyarakat mengingat perjalanan penyakitnya yang cepat, mudah menyebar dan dapat mengakibatkan kematian dalam waktu yang singkat. Jumlah penderita DBD tahun 2017 turun menjadi 299 kasus dengan angka kesakitan sebesar 18,14 dan angka kematian sebesar 2,7 \%, dari 488 kasus dengan angka kesakitan sebesar 25,22 dan angka kematian sebesar 5,13 \% pada tahun 2016. Tahun 2017 merupakan tahun dengan jumlah kasus terendah sejak tahun 1994. Terjadi penurunan IR yang signifikan dari tahun 2016 dari 25,22 menjadi 18,14 pada tahun 2017. Case Fatality Rate (CFR) Tahun 2017 menurun, dari 5,13 pada Tahun 2016 menjadi 2,7 pada tahun 2017 (Profil Puskesmas Pudakpayung, 2017). Puskesmas Pudakpayung adalah unit pelaksana teknis Dinas Kesehatan Kota Semarang yang menyelenggarakan pembangunan kesehatan di suatu wilayah kerja dan merupakan ujung tombak pelayanan kesehatan Pemerintah yang berfungsi memberikan pelayanan kesehatan dasar bagi masyarakat. Wilayah kerja Puskesmas Pudakpayung termasuk daerah endemis DBD, meskipun jumlah kasus menurun 4 tahun terakhir tetapi masih terdapat kasus Demam dengue (DD) (Profil Puskesmas Pudakpayung, 2017). Upaya yang dilakukan Puskesmas Pudakpayung untuk mengendalikan penyakit DBD diantaranya pencegahan (Pemberantasan Sarang Nyamuk (PSN)/PSN 3M Plus, pemeriksaan jentik dan penyuluhan kesehatan), penanggulangan (Surveilans Epidemiologi (SE), Penyelidikan Epidemiologi (PE), musyawarah masyarakat, penyuluhan DBD, PSN, larvasidasi, fogging focus, foging massal, dan tatalaksana penanggulangan kasus), dan menempatkan petugas surveilans kesehatan (Gasurkes) di masing-masing kelurahan. Selain itu ada Penyelidikan Epidemiologi (PE), inovasi untuk menurunkan kasus secara kimia: fogging/pengasapan, obat nyamuk bakar, semprot atau repellent dan abatisasi/penaburan bubuk abate, mekanis (Gerakan $3 \mathrm{M}$ dan $3 \mathrm{M}$ Plus) dan biologis (dengan predator air kolam diisi ikan pemakan jentik, insektisida hayati, dan memanfaatkan tanaman pengusir nyamuk).

Berdasarkan uraian maka diperlukan kajian untuk mengetahui evaluasi keefektifan pelaksanaan program Surveilans Epidemiologi di Puskesmas Pudakpayung Kota Semarang tahun 2018.

\section{METODE}

Jenis penelitian ini merupakan penelitian evaluatif yaitu menilai suatu program yang termasuk penelitian telah dilaksanakan dengan membandingkan kriteria atau tujuan yang telah ditetapkan. Rancangan penelitian yang digunakan adalah penelitian deskriptif yang bertujuan menggambarkan dan menjelaskan secara sistematis fakta-fakta, sifat serta hubungan antar fenomena yang diselidiki (Notoatmodjo, 2012). Pendekatan penelitian yang digunakan adalah kualitatif untuk mendapat informasi mendalam dari informan tentang program yang sudah dilakukan, sehingga penelitian ini mampu menggambarkan keadaan yang sebenarnya di lapangan. Hasil dari penelitian akan dibandingkan dengan teori surveilans epidemiologi.

Obyek penelitian adalah program surveilans epidemiologi di bagian Pencegahan dan Pemberantasan Penyakit Menular (P2M) Puskesmas Pudakpayung. Informan dalam penelitian ini berjumlah 4 orang terdiri dari Kepala Puskesmas Pudakpayung, 1 orang penanggung jawab program P2M DBD dan pelaksana program surveilans epidemiologi, Kepala Seksi Perencanaan, dan 1 orang pada bagian keuangan.

Teknik pengumpulan data program surveilans diperoleh melalui wawancara mendalam dengan menggunakan instrumen panduan wawancara dan observasi dokumen untuk melihat pelaksanaan program surveilans epidemiologi oleh Puskesmas 
Pudakpayung. Data sekunder program surveilans diperoleh dengan studi dokumen tentang jumlah petugas surveilans epidemiologi serta sarana dan prasarana yang ada di Puskesmas Pudakpayung. Analisis data program surveilans dilakukan secara deskriptif, yaitu menggambarkan suatu keadaan yang sebenarnya berdasarkan hasil analisis dan interpretasi yang akan digambarkan dalam bentuk tabel, grafik, gambar maupun narasi (Noor, 2008).

\section{HASIL DAN PEMBAHASAN}

Dalam tahapan proses penggalian data surveilans yang dilakukan melalui wawancara dan observasi meliputi beberapa komponen pelaksanaan surveilans diuraikan sebagai berikut:

\section{Pengumpulan data}

Pelaksanaan pengumpulan data penyakit DBD dilakukan secara terus menerus agar memberikan informasi epidemiologi suatu penyakit dengan lengkap. Pengumpulan data DBD dilakukan secara aktif yang dilakukan setiap hari jika terdapat laporan tersangka DD, DBD, dengue shock syndrome (DSS) yaitu petugas surveilans Puskesmas mengumpulkan data dengan mendatangi pasien tersangka dan kasus penyakit DD, DBD, DSS dengan melakukan PE 1 X 24 jam menggunakan form Penyelidikan Epidemiologi (PE) dengan panduan buku petenjuk teknis milik Pemerintah yang sebaiknya selalu digunakan menjadi pedoman pelaksaan PE DBD. PE DBD oleh petugas surveilans Puskesmas langsung ke tersangka kasus dengan melakukan wawancara mendalam dengan sumber, orangtua atau yang merawat, tetangga terdekat dan melakukan pemeriksaan Angka Bebas Jentik (ABJ) pada 20 rumah disekitar kasus sehingga menemukan gambaran perwakilan. Pengumpulan data DBD juga dilakukan secara pasif yaitu Puskesmas menginventarisir kasus-kasus DBD yang berkunjung ke sarana pelayanan kesehatan tersebut. Media pengumpulan data dilakukan dengan menggunakan form Penyelidikan Epidemiologi (PE) resmi yang dikeluarkan pemerintah. Berikut ini tabel Standar Operasional Prosedur (SOP) Pelacakan Epidemiologi Puskesmas Pudakpayung:

Tabel 1. Standar Operasional Prosedur (SOP) Pelacakan Epidemiologi Puskesmas Pudakpayung

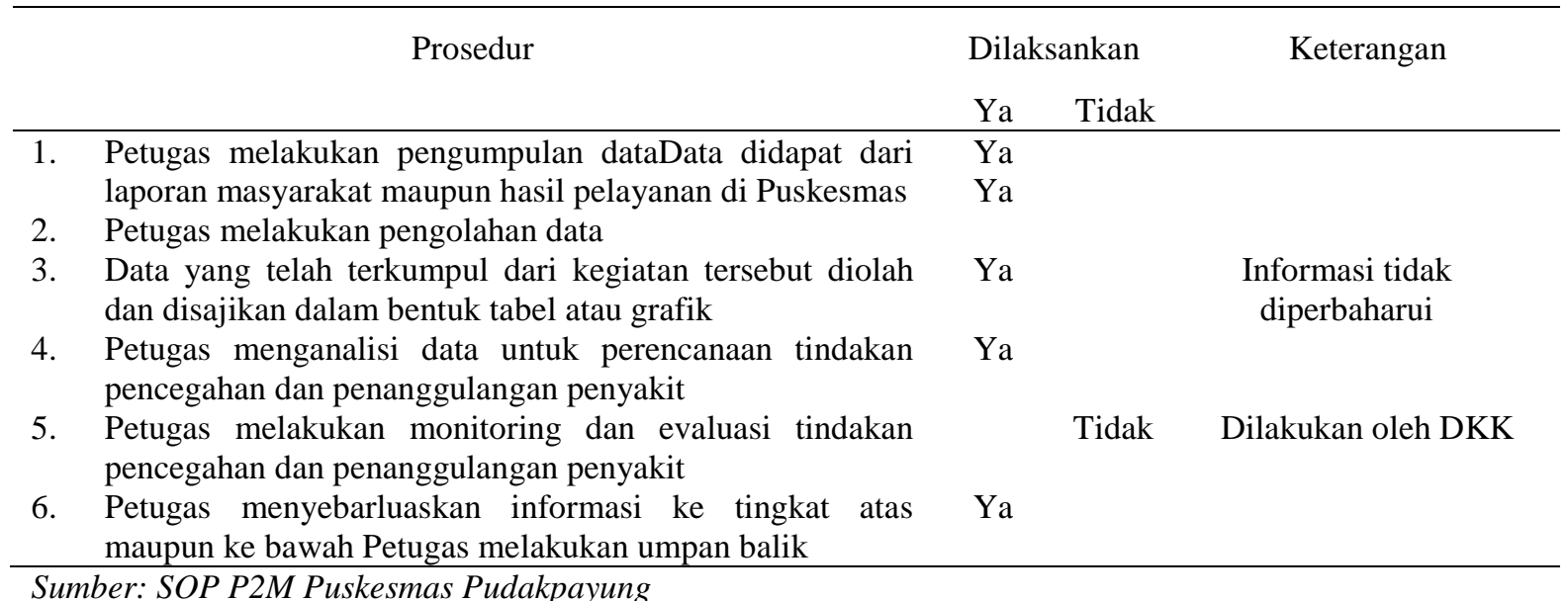

Berdasarkan Tabel 1. Puskesmas Pudakpayung telah menjalankan pelacakan epidemiologi sesuia dengan SOP. Data-data yang diperoleh diinput ke sistem Health Early Warning System (HEWS) DBD dimana merupakan sistem peringatan dini yang dapat memprediksi kasus DBD yang terdampak oleh perubahan iklim dengan menggunakan data curah hujan, hari hujan, kelembaban udara, dan suhu udara yang disediakan oleh BMKG untuk menjadi input formula. Sistem ini membantu Dinas Kesehatan dalam 
mendokumentasikan pelaporan temuan kasus DBD dari masyarakat, sekolah, serta Puskesmas dan Rumah Sakit. Masyarakat dan sekolah dapat melaporkan melalui SMS. Puskesmas Pudak paying memiliki akun untuk dapat mengisi laporan secara online. Sistem SMS juga dihubungkan ke pemangku kepentingan seperti lurah dan camat yang memiliki wewenang untuk mengambil tindakan jika ada kasus di lingkungannya. Selain itu, sistem pelaporan baik pelaporan program Pemantauan Jentik, Penyelidikan Epidemiologi, Fogging dan respon keluhan masyarakat akan terlaporkan lewat sistem ini.

Hardcopy Form PE diberikan ke Dinas Kesehatan Kota (DKK) Semarang dan semua kasus DD, DBD, dan DSS direkap setiap minggu dan tiap bulan untuk di evaluasi bersama dengan Gasurkes, P2M Puskesmas untuk menentukan langkah-langkah dalam pencegahan dan pengendalian. Penyampaian laporan kasus DD, DBD, dan DSS selambatlambatnya 24 jam setelah diagnosis ditegakkan. Dari hasil pengamatan dan wawancara, data yang ada sudah lengkap, untuk meningkatkan keakuratan data petugas melakukan surveilans aktif melalui program PE. Kasus DD, DBD dan DSS berdasarkan sumber informasi data dan petugas melakukan surveilans pasif dengan meng cross-check data nama-nama pasien DD, DBD dan DSS yang masuk apakah terdapat data ganda antara laporan kunjungan di Puskesmas dengan laporan yang diberikan oleh fasilitas pelayanan kesehatan lain maupun oleh Gasurkes di Kelurahan. Ketepatan waktu laporan ditargetkan setiap bulan. Data yang ada akan di kumpulkan di bagian Sistem Pencatatan dan Pelaporan Terpadu Puskesmas (SP2TP). Form absensi ketepatan dan kelengkapan laporan sudah dibuat oleh petugas dan program tersebut dilakukan setiap bulan.

\section{Pelaksanaan pengolahan dan analisis data serta penyajian data DBD}

Pelaksanaan pengolahan dan analisis serta penyajian data penyakit DBD sangat penting, namun kemampuan ini diperlukan keterampilan petugas dalam penugasan teknik pengolahan dan analisis data. Pada pengolahan dan analisis data sangat tergantung dengan tingkat unit kesehatan dan keterampilan petugas di tiap unit kesehatan.

Dari hasil obeservasi menunjukkan bahwa data kasus DBD dilakukan pengisian di komputer secara rutin. Data yang di rekap sudah dilakukan analisis lebih lanjut, sehingga informasi yang dibutuhkan mengenai DBD di wilayah kerja puskesmas Pudakpayung seperti penyajian data berupa diagram dan grafik sudah ditampilkan. Penyajian data berupa diagram dan grafik DBD perlu diletakkan di posisi-posisi tertentu seperti papan informasi 10 penyakit tertinggi dan dilakukan update setiap bulan dan tahun. Dari hasil wawanacara dan observasi dilapangan diketahui untuk pelaksanaan pengolahan dan penyajian data sudah maksimal namun tidak dilakukan update pada papan informasi Puskesmas. Pengolahan data dilakukan oleh pengelola program.

Sumber Daya Manusia (SDM) yang bertugas sebagai pemagang program merangkap sebagai pemegang program dan petugas surveilans, berikut tabel Sumber daya tenaga di Puskesmas Pudakpayung tahun 2018: 
Tabel 2. Sumber daya tenaga di Puskesmas Pudakpayung tahun 2018

\begin{tabular}{lc}
\hline \multicolumn{1}{c}{ Jabatan } & Jumlah (orang) \\
\hline 1. Kepala Puskesmas & 1 \\
2. Kasubag TU & 1 \\
3. Dokter Umum & 2 \\
4. Dokter Gigi & 2 \\
5. Bidan & 2 \\
6. Perawat & 3 \\
7. Perawat Gigi & 1 \\
8. Penyuluh & 1 \\
9. Farmasi & 1 \\
10. Nutrisionis & 1 \\
11. Sanitarian & 1 \\
12. Analis & 1 \\
13. Epidemiolog & 1 \\
14. Administrasi & 2 \\
15. Rekam Medik & 1 \\
16. Sopir & 1 \\
17. Cleaning Servis & 3 \\
\hline \multicolumn{2}{c}{ Jumlah } \\
\hline Sumber: Profil Puskesmas Pudakpayung tahun 2018
\end{tabular}

Berdasarkan Tabel 2. Petugas pemegang program dan pelaksana surveilans DBD multijobdes karena keterbatasan SDM. Puskemas Pudakpayung tidak memiliki SDM surveilans khusus, selama ini program surveilans masih melekat pada program sehingga petugas program juga merangkap sebagai petugas surveilans dengan latar belakang pendidikan S1 Kesehatan Masyarakat peminatan Epidemiologi hal ini sesuai dengan sesuai dengan pasal 88 dan pasal 96 Undang-Undang no 36 Tahun 2014 tentang SDM Kesehatan dsebutkan bahwa SDM kesehatan yang diijinkan berprofesi minimal berijazah Diploma Tiga (D III) namun hal tersebut tidak menjadi hambatan untuk melaksanakan SE DBD secara maksimal, karena petugas surveilans DBD di Puskesmas juga dibantu dari Gasurkes di tingkat Kelurahan. Surat Keputusan (SK) petugas surveilans tercantum dalam job descriptons petugas.

\section{Interpretasi data dan rekomendasi}

Dalam program ini diperlukan kemampuan dan keterampilan petugas menguasai teknik, metode tertentu dalam menginterpretasi data seperti juga pada pengolahan dan analisis data. Penentuan interpretasi dan rekomendasi data juga sangat tergantung dengan tingkat unit kesehatan dan keterampilan petugas surveilans di tiap unit kesehatan. Dari hasil wawancara dengan petugas pelaksanaan interpretasi dan rekomendasi data sudah dilakukan. Data secara akumulatif juga dibuat dalam bentuk Power Point (PPT) untuk dipresentasikan pada forum lintas sektor yang meliputi Kelurahan, PKK, Kader, Bintara Pembina Desa (Babinsa), Bhayangkara Pembina Keamanan dan Ketertiban Masyarakat (Babinkamtibmas), RT/RW, dan tokoh masyarakat dibalai Desa/Kelurahan untuk tindakan penanggulangan yang disepakati secara bersama.

\section{Pelaksanaan penyebarluasan informasi dan umpan balik}

Kunci keberhasilan surveilans adalah memberikan umpan balik kepada sumbersumber data surveilans agar mudah memberikan kesadaran kepada sumber data tentang pentingnya proses pengumpulan data sehingga memberikan informasi yang mudah dimengerti dan dimanfaatkan dalam menentukan arah kebijakan program surveilans serta pengambilan keputusan. Program feedback ke sumber data belum dilakukan. Menurut 
petugas bahwa diseminasi informasi disampaikan pada saat lokakarya mini (lokmin) Puskesmas yang dilakukan 1 bulan 1 kali, sedangkan lintas sektor dilakukan pada pertemuan di Dinas Kesehatan, sedangkan pada masyarakat dilakukan dalam program apel pagi Pemberantasan Sarang Nyamuk (PSN) untuk menginformasikan penemuan kasus di wilayah Puskesmas Pudakpayung sehingga masing-masing lintas sektor mengetahui program dan capaian dari bidang kesehatan khususnya penyakit DBD. Pelaksanaan penyebarluasan informasi sudah memadai dan umpan balik dilakukan oleh Puskesmas, penyebarluasan informasi dalam bentuk pengiriman data ke Dinas Kesehatan rutin dilakukan melalui aplikasi HEWS DBD.

\section{Hasil analisis kebutuhan data surveilans DBD}

Input terdiri dari Perencanaan Tahunan Puskesmas (RTP) untuk menyusun rencana program surveilans pelaksanaan program DBD Pudakpayung. Rencana program terutama preventif dan promotif. Beban kerja petugas pengelola program DBD memiliki pekerjaan lain disamping pekerjaan inti. Pengelola program DBD juga merangkap sebagai pengelola surveilans penyakit, pengelola program DBD puskesmas, dan pemegang program P2, semua program program pencegahan dan pemberantasan penyakit harus dipantau dan dipegang oleh 1 (satu) pengelola program DBD. Pengelola program DBD di Puskesmas Pudakpayung pernah mendapatkan pelatihan mengenai surveilans, pengelola program sering mengikuti pertemuan tentang pengelolaan program DBD dari program pertemuan yang diselenggarakan oleh DKK Semarang. Dalam penemuan kasus melibatkan dokter dan laboran terlatih yang sudah mampu mendiagnosis dan melakukan pengujian dahak pada suspek. Ketersediaan dana (anggaran) program surveilans DBD sangat minim. Alokasi anggaran berasal dari anggaran BOK (Bantuan Operasional Kesehatan). Ketersediaan sarana dan prasarana seperti kurangnya kendaraan dinas sehingga menggunakan kenadaraan pribadi, sebagai penunjang program diperlukan buku pedoman penting bagi petugas khususnya dan puskesmas sebagai rujukan program dan Standar Operasional Prosedur (SOP). Ketersediaan buku pedoman sangat diperlukan misalnya tatalaksanan pengobatan bagi penderita, dan lain-lain. Tetapi pada saat observasi lapangan karena ada akreditasi Puskesmas penataannya lebih dirapikan kembali, sehingga apabila petugas membutuhkan segera mudah dicari.

Proses, dalam komponen beberapa data yang sudah tersedia dan disimpan oleh petugas antara lain data kasus DBD perorangan, data cakupan PE, data kasus dan kematian DBD mingguan dan bulanan, tersedia grafik kasus DBD, tersedia data hasil program pemantauan abj, tersedia data kasus DBD perdesa/kelurahan, buku pedoman DBD, laporan program pelaksanaan program DBD.

Output dari pelaksanaan surveilans DBD yang dinilai yaitu: surveilans penyakit DBD dilaksanakan dengan target $100 \%$, hasil dari program ini adalah telah dilakukannya 12 kali dalam setahun (bulanan) penyediaan informasi yang tepat waktu dari kasus penyakit DBD dari target sebesar 12 kali dalam setahun atau realisasi 100\%, sehingga outputnya adalah ketepatan laporan PE DBD dan DD <24 Jam terpenuhi.

\section{Monitoring dan Evaluasi Pelaksanaan Program Surveilans DBD}

Monitoring dilakukan melalui mini lokakarya setiap 1 bulan sekali di Puskesmas. Ketepatan laporan PE DBD dan DD <24 jam menurut Standar Pelayanan Minimal (SPM) bidang kesehatan bahwa Indikator target PE yang harus dicapai oleh Kabupaten/Puskesmas adalah sebesar $100 \%$. Data kasus DD dan DBD yang ada di Puskesmas telah dilakukan analisis. 


\section{KESIMPULAN}

Ada beberapa kelemahan dan hambatan dalam program surveilans epidemiologi kesehatan. Hambatan dan kelemahan ditemukan dari variabel berikut ini:

1. SDM pengelola program DBD yang ada di Puskesmas Pudakpayung masih kurang dan beban kerja multijobdes.

2. Minimnya dana untuk program SE DBD.

3. Kurangnya kendaraan dinas sehingga petugas harus menggunakan kendaraan pribadi.

4. Kurangnya ketertiban dan kerapian dalam meletakkan dokumen-dokumen pendukung seperti buku-buku pedoman SE

5. Perlu dilakukan pembaharuan laporan pada papan informasi Puskesmas menurut orang, tempat dan waktu sehingga pengunjung Puskesmas dapat memperoleh informasi terbaru mengenai kasus DBD di Pudakpayung.

6. Surveilans Epidemiologi sudah mencukupi dari indikator yang ditetapkan oleh Kementerian Kesehatan RI, dimana program pengumpulan data mulai kelengkapan dan ketepatan data sudah melebihi $80 \%$.

7. Output atau keluaran hasil surveilans yang dilakukan oleh Puskesmas Pudakpayung dalam bentuk laporan secara vertikal maupun horizontal sudah cukup baik. Pelaporan telah dilakukan secara rutin ke DKK Semarang dan tidak pernah terjadi keterlambatan.

\section{SARAN}

Bagi peneliti selanjutnya dapat melakukan penelitian yang lebih mendalam mengenai sistem surveilans DBD terpadu dimana variabel sistem yang digali tidak hanya berasal sistem epidemiologi Puskesmas Pudakpayung melainkan menggali data untuk sistem epidemiologi DBD Puskesmas Pudakpayung dengan lintas program maupun lintas sektor dalam pelaksanaan surveilans DBD.

\section{DAFTAR PUSTAKA}

Kementerian Kesehatan RI. 2018. InfoDatin Situasi Demam Berdarah Dengue (DBD). Journal of Vector Ecology. Hal. 71-78. DOI: 10.3376/1081 1710(2006)31[71:aomtva]2.0.co;2.

Suwanmanee, S. et al. 2018. Monitoring arbovirus in Thailand: Surveillance of dengue, chikungunya and zika virus, with a focus on coinfections. Acta Tropica. Elsevier, 188(September). Hal 244-250.

DOI: 10.1016/j.actatropica.2018.09.012.

CDC. 2010. Epidemiology Dengue Homepage.

Yuningsih, R. 2018. Kebijakan Penanggulangan Kejadian Luar Biasa Penyakit Demam Berdarah Dengue di Kabupaten Tangerang. Jurnal Masalah Masalah Sosial, Vol 9. No. 2.Hal. 260-273.

Nurhidayati, I. et al. 2015. Gerakan Bebas Nyamuk sebagai Upaya Pencegahan dan Penanggulangan Demam Berdarah di Desa Gedaren Kecamatan Jatinom Kabupaten Klaten. The 2nd University Research Coloquim 2015. Hal 408-414.

Djawa, Y. D., Hariyanto, T. and Ardiyani, V. M. 2017. Pengaruh Pemberian Penyuluhan Terhadap Kemampuan Keluarga Dalam Mendeteksi Demam Berdarah Dengue (DBD) Pada Anak. Nursing News. Vol 2. No. 2. Hal 595-606. 
Kementerian Kesehatan Republik Indonesia. 2017. Data dan Informasi Profil Kesehatan Indonesia Tahun 2016.

PPJT. 2009. Tentang Provinsi Jawa Tengah.

Puskesmas Pudakpayung. 2018. Profil Puskesmas Pudakpayung.

Notoatmodjo, S. 2010. Metodologi Penelitian Kesehatan. Jakarta: Rineka Cipta.

Athiyah, Noor. (2008). Kebutuhan Informasi dan Perilaku Pencarian Informasi: Program Studi Ilmu Perpustakaan dan Informasi, FIB UI.Tesis. 